BJHS: Themes 1: 145-167, 2016. C British Society for the History of Science 2016. This is an Open Access article, distributed under the terms of the Creative Commons AttributionNonCommercial-ShareAlike licence (http://creativecommons.org/licenses/by-nc-sa/4.0/), which permits non-commercial re-use, distribution, and reproduction in any medium, provided the same Creative Commons licence is included and the original work is properly cited. The written permission of Cambridge University Press must be obtained for commercial re-use. doi:10.1017/bjt.2016.2 First published online 22 March 2016

\title{
Green-revolution epistemologies in China and India: technocracy and revolution in the production of scientific knowledge and peasant identity
}

\author{
MADHUMITA SAHA* AND SIGRID SCHMALZER**
}

\begin{abstract}
This paper juxtaposes the epistemological challenges raised by new agricultural technologies in India and China during the mid- to late twentieth century. In both places, the state actively sought to adopt the 'improved' seeds and chemical inputs of what USAID triumphantly called the 'green revolution'; however, in neither country did this imply an unproblematic acceptance of the technocratic assumptions that undergirded the US programme. India and China's distinct ideological contexts produced divergent epistemological alternatives to the US vision, with particularly important differences in the perceived relationship between the sociopolitical and technoscientific realms and also in the understanding of what constituted a 'modern' farmer. In India, critics persistently challenged the technocratic state to consider social, political and economic aspects of agrarian modernization, but radical leaders in Maoera China went considerably further in attacking the very notion that technological change could be divorced from social and political revolution. Leaders in both India and China sought to overcome 'backwardness' and 'superstition'; however, the Indian state held up examples of farmers who exemplified capitalist ideals of modernity through their willingness to take risks in pursuit of profit, while Chinese leaders valorized peasant technicians who combined experience in labour, new technical knowledge and faith in socialist revolution.
\end{abstract}

In 1968 the director of the US Agency for International Development (USAID), William Gaud, coined the term 'green revolution'. He said,

Record yields, harvests of unprecedented size and crops now in the ground demonstrate that throughout much the developing world - and particularly in Asia - we are on the verge of an agricultural revolution ... It is not a violent Red Revolution like that of the Soviets, nor is it a White Revolution like that of the Shah of Iran. I call it the Green Revolution. ${ }^{1}$

* 1001 City Avenue, Wynnewood, PA 10196, USA. Email: madhumitasaha30@gmail.com.

** History Department, University of Massachusetts, Amherst, USA. Email: sigrid@history.umass.edu.

1 William Gaud, AID Supports the Green Revolution, address before the Society for International Development, 8 March 1968, Washington, DC: Agency for International Development, 1968. The discussion of the coining of the term 'green revolution', together with the material below relating to the green revolution in China, draws from Sigrid Schmalzer, Red Revolution, Green Revolution: Scientific Farming in Socialist China, Chicago: The University of Chicago Press, 2016. 
Thus, in the eyes of its US creators, the green revolution was not just a set of agricultural technologies designed to increase crop yields. It was also an ideologically explicit sociopolitical strategy. If farmers around the world could be raised from poverty through technological improvements to agriculture, they might be less likely to seek solutions less palatable to US political interests. The green revolution was thus a fundamentally Cold War concept. ${ }^{2}$ Gaud painted the choices facing developing countries in broad, bold strokes of red, white and green - with red symbolizing political revolution along socialist lines, white signifying theocracy and perhaps by extension reliance on traditional cultural forms more generally, and green representing a rational approach employing technological change to solve poverty and unrest.

The reality, of course, was much more complicated. The technologies of the green revolution - high-yielding varieties of seeds along with the chemical inputs that supported them - and the technocratic vision underlying green-revolution ideology did not necessarily go hand in hand: it was possible to adopt the specific technologies alongside a commitment to politically engaged science, and it was possible to embrace a technocratic vision while the technologies themselves remained out of reach. Meanwhile, despite the attempts on the part of both political revolutionaries and technocrats to sidestep or even suppress traditional cultural practices, these proved remarkably resilient. An examination of the cases of China and India reveals that the process of agrarian modernization did not resolve clearly into the Cold War categories of capitalism versus socialism, nor even Gaud's somewhat more inclusive categories of capitalism versus socialism versus theocracy. ${ }^{3}$ Instead, these histories are shot through with the tensions generated by modernity and faced in different ways by all modernizing states namely the never-resolved relationships between technology and ideology, between development and equity, and between modernization and 'traditional' practices.

India and China are key examples in the transnational and comparative study of the green revolution. Each is in some ways representative of one side of the Cold War divide, but each also existed in considerable tension with the US/Soviet poles. The US interest in promoting green revolution in India grew from the concern that India might be swayed by the logic of communism. But Indian political leaders did not passively accept a position on the US 'side' of the Cold War; rather, they actively explored alternative possibilities and in fact some looked not only at Soviet accomplishments but also at China as a third potential model. ${ }^{4}$ Chinese state officials understood the intended anti-communist

2 On the green revolution in a Cold War context see especially John H. Perkins, Geopolitics and the Green Revolution: Wheat, Genes, and the Cold War, New York: Oxford University Press, 1997; Nick Cullather, The Hungry World: America's Cold War Battle against Poverty in Asia, Cambridge, MA: Harvard University Press, 2010. Other important works on the political dimensions of US promotion of the green revolution include Andrew Pearse, Seeds of Plenty, Seeds of Want: Social and Economic Implications of the Green Revolution, Oxford: Clarendon Press, 1980; and Jack R. Kloppenburg Jr, First the Seed: The Political Economy of Plant Biotechnology, Madison: University of Wisconsin Press, 2004; first published 1988.

3 We have consciously adopted the term 'agrarian modernization' rather than 'agricultural modernization' to underscore the point that the impact of green-revolution technologies, like that of all technologies, was never limited to realms of production, but rather always necessarily involved the social, political and cultural spheres.

4 Indian agricultural scientists were among the many experts who travelled to China during the Mao era to identify aspects of Maoist approaches to development that might work for India. See, for example, Netra Pal 
symbolism of the green revolution and lambasted Indian leaders for supporting it. However, no less than their Indian counterparts, Chinese officials eagerly adopted new crop varieties and chemical inputs whenever they were available. The dilemmas the Indian and Chinese states faced in grappling with the green revolution lay in the political assumptions undergirding its technocratic vision, and not in any of the specific genetic and chemical materials it comprised. The Chinese state in particular could not countenance the technocratic perspective that William Gaud and others espoused that is, the notion that science and technology are inherently apolitical forces, and further that they are not just politically neutral themselves, but even have a neutralizing effect on potential political activity, satisfying social needs and so preventing revolutionary movements from gaining steam.

With roots stretching back to the Enlightenment, the technocratic impulse grew in prominence during the twentieth century, as states increasingly called upon technical experts to realize the state's position as 'the authoritative problem solver of the needy nation'. 5 What set these 'technocrats' apart from other members of the bureaucracy was their degree of specialization (especially in certain scientific fields of practical value to the state) and their supposed ability to be neutral in decision-making. By virtue of their role in the political decision-making process, technocrats are closely entangled with political establishments. Yet central to technocracy is the expectation that scientific research can and should be disconnected from politics. In fact, a technocrat's claim to rationality is largely premised on his ability to reduce politics to technical decision-making. Thus the process of 'rendering technical' - that is, framing a problem in technical terms to make it more amenable to available technologies, rather than addressing its social and political complexities - has been essential to technocratic interventions. ${ }^{6}$

The epistemological and political assumptions behind the technocratic model of development have provided much fodder for scholarly critique. As James Ferguson wrote in 1990, "What is "development" ? It is perhaps worth remembering just how recent a question this is. This question, which today is apt to strike us as so natural, so self-evidently necessary, would have made no sense even a century ago.' He went on to argue that the 'development apparatus' is an "“anti-politics machine," depoliticizing everything it touches, everywhere whisking political realities out of sight, all the while performing, almost unnoticed, its own pre-eminently political operation of expanding bureaucratic state power'. ${ }^{7}$ And in his landmark Rule of Experts: Egypt, Techno-politics,

Jain, Rural Reconstruction in India and China: A Comparative Study, New Delhi: Sterling Publishers, 1970; and Kalyani Bandyopadhyaya, Agricultural Development in China and India: A Comparative Study, New York: Wiley, 1976.

5 Srirupa Roy, Beyond Belief: India and the Politics of Postcolonial Nationalism, Durham, NC: Duke University Press, 2007, p. 117.

6 Tania M. Li, The Will to Improve: Governmentality, Development, and the Practice of Politics, Durham, NC: Duke University Press, 2007, p. 7.

7 James Ferguson, The Anti-politics Machine: 'Development,' Depoliticization, and Bureaucratic Power in Lesotho, New York: Cambridge University Press, 1990, pp. xiii, xv. 
Modernity, Timothy Mitchell delivered a devastating critique of technocratic approaches to economic development specifically in the context of technology transfer. ${ }^{8}$

Scholars committed to a contextualized reading of the history of science and technology have been critical of the ways in which modernization narratives, couched in a 'language of technical rationality', have 'screened out' agro-ecological variance, cultural aspects of food, social inequality, and power. ${ }^{9}$ The discounting of variance in favour of developmental homogeneity, along with the related assumption of a linear and universal trajectory of growth for scientific knowledge, has additional significance for nonWestern countries. In the built-in spatial hierarchies of development discourse, the West has come to be associated with science and technology, high standards of living, and rationality - a consortium of qualities found lacking in less developed countries with 'traditional' societies. ${ }^{10}$ Discounting the significance of social, cultural and political factors, development discourses have framed the decision whether to embrace a new technology in purely 'rational' terms. People who adopt 'advanced' technologies are, ipso facto, 'modern', whereas any resistance to the latest technology is coded an act of irrationality, reflecting the mark of a static, 'traditional' society.

STS scholars and critics of development have long struggled against depoliticized and decontextualized readings of epistemology and practices. Within much of this criticism, however, is an implicit acceptance that technocratic principles have successfully caused a disjuncture between technology and politics. More recent scholarship has questioned whether technocrats have ever truly achieved depoliticization, ${ }^{11}$ or whether such a 'binary order' between human intentions and the world of experience - which is shaped by social, economic, political, cultural and ecological linkages - is even possible. ${ }^{12}$ We follow these scholars in arguing that expertise and technoscientific epistemology exist in negotiation with such linkages; we pursue this line of argument through a consideration of Indian and Chinese approaches to transforming agricultural science and technology within the larger context of Cold War-era technocracy.

We begin by exploring the different perspectives on the relationship between sociopolitical and technoscientific change articulated by Indian and Chinese actors engaged in agrarian modernization efforts. In India, the technocratic embrace of the green revolution was always mediated by challenges brought by those concerned about socioeconomic relations (including the high price of imported technologies, technological dependence on the West and a lurking fear of American hegemony over policy matters). However, supporters of the technologies countered these criticisms by emphasizing the power of modern scientific knowledge to achieve self-sufficiency in food and greater prosperity for farmers. In Mao-era China, not only were technocratic principles

8 Timothy Mitchell, Rule of Experts: Egypt, Techno-politics, Modernity, Berkeley: University of California Press, 2002.

9 Gabrielle Hecht, The Radiance of France: Nuclear Power and National Identity after World War II, 2nd edn, Cambridge, MA: MIT Press, 2009, p. 11; Li, op. cit. (6), p. 11.

10 Akhil Gupta, Postcolonial Developments: Agriculture in the Making of Modern India, Durham, NC: Duke University Press, 1998, p. 41.

$11 \mathrm{Li}$, op. cit. (6), p. 10.

12 Mitchell, op. cit. (8), p. 52. 
unsuccessful in effecting a separation of technology and politics, but also radical leaders advanced their own anti-technocratic epistemology that insisted on the 'primacy of politics'. The task facing STS scholars in the case of China is thus not so much to demonstrate the embeddedness of technology in politics, but to ask what forms of entanglement remain obscured in the radical Chinese epistemology.

We then move to a discussion of how political orientations framed understandings of the identity of farmers and the role they played in modernizing (or blocking the modernization of) agriculture and rural society. Political leaders in India and China shared a deep antipathy to what they perceived as peasant 'backwardness'; for them, building a modern nation depended on replacing peasants' traditional and 'superstitious' mindsets with a modern, scientific and future-oriented mentality. However, the stark contrasts in Indian and Chinese ideological commitments produced important differences in their visions of what a modern peasant should be. Indian modernizers sought to transform risk-averse peasants concerned with mere subsistence into risk-taking, profit-seeking individual farmers. Socialist Chinese modernizers envisioned instead a vast corps of 'peasant technicians' who could balance modern technical knowledge, faith in the revolution and lived experience in agricultural labour.

We conclude the paper by stepping back to consider these findings in light of more recent history and to place them in relation to the insights shared in other contributions to the issue.

\section{State, social reforms and scientific research in Indian agriculture}

In April 1965, as the Indian Agricultural Research Institute (IARI) celebrated its fiftieth anniversary, Pakistani incursions occurred in western India, adding substantially to national anxieties about the food situation. It was apparent by late July that the year's monsoon had failed over northern India, and as PL480 (a food aid agreement with the US signed in 1954) came to an end, India faced the danger of another famine. Prime Minister Lal Bahadur Shastri and C. Subramaniam, the union food and agricultural minister, began promoting greater use of modern agricultural science and technology as vital to the nation's security and development. ${ }^{13} \mathrm{~A}$ favourable political opinion was, therefore, created for the introduction of green-revolution seeds in India, whose supporters saw in it the solution to India's hunger and agricultural backwardness. For instance, Indira Gandhi, who succeeded Shastri, anticipated that the new technology would bring about an 'agricultural revolution', helping to feed the country's 'growing millions'. ${ }^{14}$

Although many believed that science could cure India's various developmental problems, the relation of scientific epistemology to politics remained a contentious issue. The Indian state's embrace of the US strategy of 'green revolution' did not mean

13 C. Subramaniam, 'Message', Indian Farming (1965) 15(7), p. 2.

14 Indira Gandhi on Science, Technology and Self-Reliance: Inaugural Addresses to the Indian Science Congress, Calcutta: Indian Science Congress Association, 1985, p. 10. Both Shastri and Indira had been hailed by the green-revolution scientists for the support they gave to the introduction of the technology in India. 
that its goals and perspectives fully mapped onto those of the US. If the major motives of US agencies in promoting the green revolution were to forestall communist insurrections and promote a free-market economy, the Indian government was more concerned to avoid a 'crisis of sovereignty' and retain the moral legitimacy to rule, distinguishing Indian from British rule through better food security and thus avoidance of faminerelated suffering. ${ }^{15}$ And some at least in India noticed that green-revolution reforms, far from being politically neutral, were in fact tied to very specific political and economic structures. ${ }^{16}$ The road to technocracy in India thus charted territories rife with the potential for alternative, more political, understandings of both science and hunger.

India's first prime minister, Jawaharlal Nehru (1947-1964), had been an ardent champion of science, but for him the appeal of science was not just economic. Rather, he emphasized a threefold role for science that combined solving the material problems of the nation, addressing social issues, and contributing to the development of a scientific spirit among the Indian people. Nehru even imagined that science could usher in a 'classless' Indian society. However, even as he celebrated science as the 'greatest revolutionary force of the past hundred and fifty years' ${ }^{17}$ it was not for Nehru or his followers a means of challenging entrenched power structures in society. Rather, Nehru looked to science as an alternative to the bloodshed that accompanied political revolution, and he specifically sought to avoid the experience of countries like China where socialist revolution had come only after years of violent civil war. Nor did the vision of science as a revolutionary force imply a radical epistemology: rather, postcolonial nationalists in India were adamant about maintaining the rationality and selectivity of the scientific establishment, and to them this implied its disengagement from the rough and tumble of political process. ${ }^{18}$ For Nehru, the political power of science rested, perhaps ironically, in its rationality, which was understood as a separation from politics.

Nehru's commitment to institutional reforms that promoted social equity and the democratic participation of farmers provided a further check on a fully technocratic approach to agricultural science during his administration. A strategy based dominantly on incentives to greater private investment in modern inputs and concentration of resources in the irrigated areas was not entertained because it 'might have yielded maximum gains in output, but only at the social cost of widening the gulf between large landowners and the mass of subsistence farmers on the one hand, and the most advantaged and

15 Gupta, op. cit. (10), p. 35.

16 Detailed discussions of the social, economic and political impacts of green-revolution technologies in India can be found in Francine Frankel, India's Green Revolution: Economic Gains and Political Costs, Princeton, NJ: Princeton University Press, 1971; Biplab Dasgupta, Agrarian Change and the New Technology in India, Geneva: UN Research Institute for Social Development, 1977; and Ashutosh Varshney, Democracy, Development and the Countryside: Urban-Rural Struggles in India, Cambridge: Cambridge University Press, 1995.

17 Jawaharlal Nehru, 'Building new India: talk given at All India Radio on December 31, 1952', cited in Frank Moraes, Jawaharlal Nehru: A Biography, New York: Macmillan, 1956, p. 44.

18 On the Nehru administration's commitment to keeping the 'experts' of the Planning Commission away from the political process see Partha Chatterjee, The Nation and Its Fragments: Colonial and Postcolonial Histories, Princeton, NJ: Princeton University Press, 1993; Gyan Prakash, Another Reason: Science and the Imagination of Modern India, Princeton, NJ: Princeton University Press, 1999; Roy, op. cit. (5). 
impoverished regions on the other'. ${ }^{19}$ Policymakers, therefore, insisted on the development of indigenously available biochemical inputs that would be more easily accessible to all farmers and without costing much. This planning orientation informed the agricultural scientists' decision to focus their research primarily on developing fertilizers from indigenous sources rather than relying on imported chemical fertilizers: during the Nehru era research reports from India's premier agricultural research institute, the IARI, indicate a strong emphasis on the development of inputs using locally available organic and inorganic material.

However, as the discourse on technological rationality gained strength in the late 1950s, it gradually marginalized the emphasis on mobilizing indigenous resources. In the late 1950s experts from the Ford Foundation (a key institutional sponsor of the green revolution) visited the Indian countryside to assess India's food 'crisis'. In the report they submitted to the Indian government they advocated 'an all-out emergency' programme built around large-scale adoption of expensive biochemical resources, and economic programmes to support that adoption. At the same time, they specifically discouraged land reforms as a way of improving the Indian agrarian sector, since they considered 'insecurity of tenure' brought about by land reform to have a 'retarding' effect on food production. The representatives reasoned that if well-off farmers could be assured that no further reforms would pose risks to their property, they would be encouraged to invest in new inputs and so increase production on their land. ${ }^{20}$

The Ford Foundation's insistence on technocratic reforms found many influential supporters in India's various establishments. For example, in the 1965 plan he authored titled the New Agricultural Strategy (NAS), Subramaniam broke away from Nehru's agricultural policy to urge the central importance of fertilizer and better seeds: 'To produce more food with less fertilizer is as impossible a task as to produce more steel with less iron ore ... Better seeds for agriculture are as crucial as better machine tools for industry'. ${ }^{21}$ Subramaniam assured the Indian parliament that his new 'programme', or 'formula', as he called the plan, would take India to self-sufficiency by 1971.22 Not only did Subramaniam's agricultural strategy ignore the structural causes of hunger - that is, social and economic inequality, an inefficient food distribution system and limited access to resources - but it also bypassed the social and agro-ecological complexity of the food question. Instead, laden with the task of increasing the country's food production, Subramaniam reasoned that the best way to

19 Francine Frankel, India's Political Economy, 1947-2004: The Gradual Revolution, New York: Oxford University Press, 2005, p. 95.

20 Ford Foundation, Report on India's Food Crisis and Steps to Meet It, New Delhi: Government of India, 1959 , p. 6.

21 Ministry of Food and Agriculture, Department of Agriculture, 'Agricultural development: problems and perspectives', April 1965, Appendix I.

22 India, Lok Sabha Secretariat, Lok Sabha Debates, Third Series, vol. 49, No 24, 7 December 1965, 6075. Quoted in Francine Frankel, 'India's new strategy of agricultural development: political costs of agricultural modernization', Journal of Asian Studies (1969) 28, pp. 693-710, 693. 
encourage farmers to adopt the new technological inputs would be higher price incentives. $^{23}$

Supporters of the green revolution in India exhibited confidence that nature could be subdued to serve human needs and so the technological transformation of nature would suffice for solving India's food problems. Yet their rejection of political understandings of, and solutions to, problems of hunger did not in fact make their projects apolitical. Rejecting land reform was itself a political decision. Moreover, in choosing sites for the introduction of green-revolution technologies, agricultural experts repeatedly favoured certain kinds of sociopolitical environment over others: they took into consideration not only the local hydraulic conditions and chemical properties of fertilizers in current use, but also the cultural orientation of the local farmers and the political stability of the region, preferring areas where the issues of land reform had been 'settled' for good. ${ }^{24}$

Beginning in the mid-1960s, US advisers and, especially, Indian officials tried to locate field experiments on farms that were large, highly mechanized and well irrigated. 'We had introduced the new seed in areas with irrigation facility', remarked Agriculture Secretary B. Sivaraman. ${ }^{25}$ Most such farms were in the hands of cultivators with economic resources and social capital, and so the decision to site the field experiments there could not help but be politically significant. ${ }^{26}$ And in their own way, the scientists knew this. As a prominent US green-revolution scientist put it, being 'well-educated, well-read, well-traveled, and well-informed' made a farmer more receptive to a new technology, whereas the 'thrilling success' that a technology could enjoy might turn into 'disappointing failures' if introduced among cultivators who were 'impoverished, illiterate, isolated, suspicious of strangers' ${ }^{27}$ Indian scientists validated these assumptions through studies on the 'relationship between the attitude of the farmers and certain socio-cultural variables'. They showed that a 'higher level of income, better schooling of farmers and the large holdings accelerate the rate of acceptance of improved practices in agriculture'. ${ }^{28}$ What the scientists did not discuss was the relationship between the attributes of an individual farmer and the social and economic privileges produced by his position in the rural power structure. In their discourse on development and technoscientific knowledge, the green-revolution experts 'screened out' any references to power relations, not to speak of the need to change them.

$23 \mathrm{He}$ was not alone in thinking along that line; the agricultural specialists and economists, especially American experts with the Ford Foundation, the Rockefeller Foundation and the US Department of Agriculture, gave him similar advice. Frankel, op. cit. (22), p. 693.

24 Dorris D. Brown, Agricultural Development in India's Districts, Cambridge, MA: Harvard University Press, 1971, p. 8.

25 B. Sivaraman, Bitter Sweet: Governance of India in Transition, New Delhi: Ashish Publishing House, 1991, p. 318.

26 On the impact of selective application of green-revolution technology see J. Mohan Rao and Servaas Storm, 'Distribution and growth in Indian agriculture', in Terence J. Byres (ed.), The Indian Economy: Major Debates since Independence, Delhi: Oxford University Press, 1998, pp. 193-248.

27 E.C. Stakman, Richard Bradfield and Paul C. Mangelsdorf, Campaigns against Hunger, Cambridge, MA: Belknap Press, 1967, pp. 207-211.

28 K.K. Das and D.R. Sarkar, 'Attitude of farmers toward 'Taichung Native I', a high-yielding variety of rice', Indian Journal of Agricultural Science (1970) 40, pp. 59-64, 61-62. 
Despite the significance of farmers' political participation in the early post-independence institutional reforms, this democratic ideal did not figure prominently in ideas about the production of agricultural scientific knowledge. The role of farmers was restricted mostly to the implementation of research results: recording their responses, working to convince them of the superiority of the new technologies, or using their fields for observation purposes beyond the controlled environ of the laboratory. ${ }^{29}$ When the All India Coordinated Projects were launched to test new seed varieties in various agro-ecological conditions, B.P. Pal (from 1965 to 1972 the head of the Indian Council of Agricultural Research) created the position of crop coordinator. ${ }^{30}$ Drawn from among the Indian government's cadre of agricultural scientists, crop coordinators were made solely responsible for 'assessing the suitability of the different varieties for different zones in the country'. They also were to 'suggest improvements to the plant breeders' after testing the new seeds in the farmers' fields. ${ }^{31}$ Similarly, the national demonstration scheme, also known as the Lab to Land Programme, underscored the privileged position of scientists. By 1976 the National Commission of Agriculture observed that researchers had turned demonstrations into a mere 'formality' as they were reluctant to submit their work for scrutiny by the farmer in his fields under ordinary farm conditions. $^{32}$ Thus, though use of locally available farming inputs received priority under the plan, there were no efforts to systematize or employ the empirically rich body of farmers' knowledge. Such so-called folklore had no place in the development regime's language of laboratory, model farm, efficiency and statistics. ${ }^{33}$

By the mid-1970s, the green revolution met increasingly stringent criticism from different quarters in India for its lack of focus on the 'unstable environment' and 'small, resource-poor farmers'. International agricultural research centres responded to these criticisms but on their own terms - that is, technologically. Developing technologies suitable for resource-poor farmers would, they hoped, prevent rural proletarianization and social conflict, and would preserve the pre-eminent role of technocrats in development matters. ${ }^{34}$ Farming Systems Research (FSR) was one of the earliest such strategies. Instead of seeing a farm as a 'collection of crops and animals', researchers decided to adopt a systemic approach to farming in which soil, plants, implements, workers and environmental influences were understood as components of a 'complicated interwoven

29 Arguably, the expression 'green revolution' posed a major ideological obstacle to the recognition of people's potential creativity, as it implied breaking with old farming systems and techniques. Pierre Spitz, 'The Green Revolution re-examined in India', in Bernhard Glaeser (ed.), The Green Revolution Revisited, London: Allen \& Unwin, 1987, pp. 56-75, 58.

30 When Subramaniam undertook the reorganization of ICAR as part of his new strategy on Indian agriculture, he appointed B.P. Pal as the first scientist to be the director general. M.S. Swaminathan, 'Dr. B.P. Pal and India's agricultural renaissance', in V.L. Chopra, R.P. Sharma, S.R. Bhat and B.M. Prasanna (eds.), Search for New Genes, New Delhi: Academic Foundation, 2007, pp. 39-53, 26.

31 Sivaraman, op. cit. (25), p. 309.

32 Sivaraman, op. cit. (25), p. 310.

33 David Ludden, 'India's development regime', in Nicholas Dirks (ed.), Colonialism and Culture, Ann Arbor: University of Michigan Press, pp. 247-288, 270.

34 Bernhard Glaeser, The Green Revolution Revisited: Critique and Alternatives, London: Routledge, 1987, p. 19. 
mesh'. ${ }^{35}$ Understanding the cultivator's world as he visualized it became the focus of FSR, which explicitly acknowledged the significance of both natural and socio-economic factors. Yet even as they recognized rural inequities, FSR proponents reframed the problem in technical terms of constraints to high yields. Without entering into social or political dialogue with affected groups, technologists sought agronomical or biological solutions. For instance, pest and soil management experts explored cultural and biological control techniques instead of using expensive agro-chemicals. While preferable from an ecological perspective, it is important to note that such solutions were also preferable to power holders as they did not require sociopolitical change and, moreover, enabled the government, technologists and even farming agencies to retain control over the development process. ${ }^{36}$

In sum, from Nehru's days as the prime minister of India through the green-revolution years, science and technology's evolution as a sociopolitical strategy underwent important changes. Nehru expected science to help achieve social goals of modernization, but he desired to keep it away from political processes. The attempt to frame science and technology in apolitical, technocratic terms gained strength under subsequent administrations. Though successful in raising food crop production, green-revolution experts faced criticisms that led them to reorient research priorities towards the needs of resource-poor farmers. However, incorporating social concerns in formulating research agendas did not necessarily imply concessions to political activism. Making research results more widely accessible, the technocracy in India sought to perpetuate its elevated status as experts who worked for the common good and without class interests. The new shifts in agricultural research further broadened the role of technocrats and the power of the technocratic mindset, restricting the role of political engagement on the part of India's scientific community.

\section{China's red-revolutionary approach to green revolution}

The decision in India to embrace the green revolution as an approach to solving poverty did not escape the notice of Chinese leaders. In 1969, People's Daily reported that India's minister of food and agriculture had "cried out in alarm that if the "green revolution"... does not succeed, a red revolution will follow'. ${ }^{37}$ For the benefit of its readers, the paper defined 'green revolution' as 'the so-called "agricultural revolution" that the reactionary Indian government is using to hoodwink the people'. Indeed, India was one of the key targets of Cold War-era US foreign aid precisely because communism had strong footholds there; throughout the Cold War, there was a real possibility that India might embrace communism by following the models of one of its two close neighbours, the Soviet Union and the People's Republic of China. And so it is not surprising that

35 Glaeser, op. cit. (34), 28.

36 The officials associated with the Consultative Group on Agricultural Research were apprehensive that addressing rural proletarianization (a fallout of the green revolution) in terms of distribution and equity would 'narrow its technological mandate'. They preferred research programmes that made farming 'attractive and profitable for the resource-poor farmer'. Glaeser, op. cit. (34), pp. 26-27.

37 'Zhengzhi jingji weiji riyi jiashen', Renmin ribao, 25 October 1969, p. 5. 
China's dominant newspaper, a mouthpiece of the Chinese Communist Party, should interpret the embrace of US-sponsored green revolution in India as undermining the possibility for communist revolution.

Yet the relationship between technoscientific (green-revolutionary) and sociopolitical (red-revolutionary) approaches to transformation was no less complex and contested in China than it was in India. During the Cultural Revolution (1966-1976), radicals identified what they called a 'two-line struggle' between people taking the 'capitalist road' and considering 'technology as \#1' on the one hand, and people hewing to the 'mass line' and placing 'politics in command' on the other. Indeed, China's adoption in the 1960s and 1970s of new agricultural technologies had the support of 'moderates' and 'radicals' alike, and it represented both faith in technological improvement and commitment to social transformation. ${ }^{38}$ However, given the political connotations associated with the term 'green revolution', it is no surprise that the Chinese state did not adopt it, but rather continued to employ terms that had grown out of Chinese efforts to transform agricultural science - most importantly, 'scientific farming' (kexue zhongtian), which emerged in the immediate wake of the Great Leap Forward (1958-1960).

During the Great Leap Forward, Mao had launched a rapid, radical reorganization of economic relationships, and many at the time blamed him (as many more do today) for the famine that subsequently claimed tens of millions of lives. The early 1960s thus offered a window of opportunity for 'moderates' to push for a reintroduction of family farming and for a renewed emphasis on professional education, especially in science and technology. The National Conference on Agricultural Science and Technology Work - mandated by the Tenth Plenum and held in early 1963 - represented this potential for a less radical and more technocratic direction in agriculture. Some of the specific programmes put into place were to remain important throughout the Mao era. In particular, the conference resulted in the expansion of the system of demonstration fields (yangbantian, literally 'model fields'), where newly introduced seeds and agricultural methods could be tested for suitability to local conditions and their worth demonstrated to local people. This system was one of a number of aspects of Mao-era agricultural extension modelled directly (though never explicitly) on the US extension system that had been popularized in pre-1949 China and with which Chinese agricultural scientists educated in the US - along with Indian scientists advised by US experts would certainly have been very familiar. It was in the reporting of this conference that People's Daily first referenced the 'Four Modernizations' - in agriculture, industry, national defence and science and technology - that Deng Xiaoping would pick up fifteen years later as the banner of his new, technocratic political agenda. At that conference, it was Marshall Nie Rongzhen, head of the State Science and Technology Commission, who called for the Four Modernizations. ${ }^{39}$ An article on the conference published a few months later referenced the Four Modernizations again and approvingly

38 A systematic overview of the green-revolution technologies adopted in Mao-era China can be found in Leslie T.C. Kuo, The Technical Transformation of Agriculture in Communist China, New York: Praeger, 1972.

39 'Chanming nongye kexue gongzuo renwu', Renmin ribao, 22 February 1963, p. 1. In January, Zhou Enlai had referenced the 'four modernizations' at a Conference on Scientific and Technological Work held in Shanghai, but had not explicitly spelled out what they comprised. See 'Zai Shanghai juxing de kexue 
quoted President Liu Shaoqi as saying that the Four Modernizations 'will depend on the hard work of everyone in the nation, depend on the hard work of the scientists, and especially will require the leadership of the old scientists'. The 'masses' appeared in the last line of the article - an afterthought at most. ${ }^{40}$

Just weeks after the conclusion of the conference, Mao articulated a very different vision of science:

Class struggle, the struggle for production, and scientific experiment are the three great revolutionary movements for building a mighty socialist country. These movements are a sure guarantee that Communists will be free from bureaucracy and immune against revisionism and dogmatism, and will forever remain invincible.

It is hard to imagine a position further removed from that of William Gaud or C. Subramaniam. The technologies of the green revolution were not a problem, but the green-revolutionary notion that technological improvement should pre-empt social and political transformation represented the worst kind of reactionary scientific ideology. In contrast, Mao and other radicals in socialist China portrayed science as a 'revolutionary movement' alongside the political struggle to topple class-based hierarchies and the economic struggle to transform China's material base through a socialist organization of labour.

Within a year of Mao's coining of the 'three great revolutionary movements', efforts to promote 'scientific farming' had become clearly infused with a much greater class politics. In May 1964, People's Daily reported the emergence of a 'new thing': mass scientificexperiment groups (qunzhongxing kexue shiyan xiaozu). ${ }^{41}$ While demonstration farms were still central to scientific farming initiatives, by autumn of 1964 they were portrayed as a means to bring together the 'expert research' of the scientific research establishment and the mass scientific-experiment movement. ${ }^{42}$ In this movement, we find a crystallization of what was to remain a central principle in agricultural research and extension throughout the Cultural Revolution: the sociopolitical and technoscientific were necessarily intertwined.

The integration of the sociopolitical and technoscientific realms meant that scientific knowledge should be produced through socially and politically revolutionary means. In official reports, one of the most universally noted characteristics of scientificexperiment groups was the 'three-in-one' (sanjiehe) composition that brought cadres, 'educated youth' and 'old peasants' together. According to a typical explanation, 'Cadres have confidence, youth have technology, and old poor peasants have experience.' The report went on to elaborate that cadres grasp all aspects of the situation, such that they can determine what kinds of experiment will best serve production

jishu gongzuo huiyi shang Zhou Enlai chanshu kexue jishu xiandaihua de zhongda yiyi', Renmin ribao, 31 January 1963 , p. 1.

40 Lü Xinchu and Gu Mainan, 'Shi kexuejia daxian shenshou de shihou le: Quanguo nongye kexue jishu gongzuo huiyi ceji', Renmin ribao, 6 April 1963, p. 2.

41 'Ba puji xiandai nongye kexue jishu jianli zai qunzhong de jichu shang', Renmin ribao, 21 May 1964, p. 1.

42 "“Yangbantian" shi nongye kexue wei shengchan fuwu de zhuyao zhendi', Renmin ribao, 25 October 1964 , p. 1. 
needs; old peasants are down-to-earth and unconcerned with profit and fame, understand the rhythms of production, and have a wealth of practical knowledge; and youth have technological knowledge and are accepting of new technologies, such that they 'dare to think and dare to act'. ${ }^{43}$ This constantly cited model is an example of a highly articulated, structured-standpoint epistemology in which three groups each perform a specific socially engendered role in the production of politically legitimate scientific knowledge.

Scientific-experiment groups were not only expected to derive from revolutionary social relationships, but were further expected to actively transform rural society and culture even as they were transforming agriculture. For example, in 1975 the journal Guangxi Agricultural Science celebrated the work of a team of teenage girls, named the March 8th Agricultural Science Group in honour of International Women's Day. The girls had applied pig manure to an underperforming field, which constituted a victory for 'scientific farming'. This was clearly not because their method involved a new technology: animal manure is, of course, a very old means of increasing soil fertility. But neither was it some kind of valorization of 'traditional' farming: while Mao had spoken in favour of fertilizing with pig manure and communities were encouraged to employ any and all local organic resources to achieve higher production levels and greater self-sufficiency, the state was simultaneously promoting chemical fertilizers to the greatest extent possible given limited supplies. The efforts of the March 8th group were celebrated as 'scientific farming' because they challenged unscientific, old, sexist ideas about women's farming abilities. They reportedly faced criticism from people who said, 'Women have never done anything important. Girls doing scientific farming?! That's like frogs at the bottom of a well trying to grow feathers and fly away!' Their response was to 'struggle fiercely against this pattern of declining sexist class consciousness ... Engaging in struggle made us realize that women practising scientific farming constitutes a deep revolution in consciousness' ${ }^{44}$

In sum, the 1960s and 1970s in China witnessed concerted efforts to raise agricultural production and, just as in India, these efforts occurred in a political terrain in which tensions between the technoscientific and the sociopolitical, the foreign and the indigenous, the chemical and the organic, played highly influential roles. The crucial difference is the balance found between technological and political approaches. In India that balance fell very heavily towards technocracy, while, especially during the Cultural Revolution, the Mao-era Chinese state explicitly urged replacing the technocratic mindset 'technology as \#1' (jishu diyi) with a strict commitment to maintaining 'politics in command' (zhengzhi guashuai). ${ }^{45}$

A question worth asking is whether at the end of the day those years of anti-technocratic agitation resulted in any less technocratic an approach to agricultural science. After the death of Mao in 1976 and subsequent repudiation of radical politics, the

43 Guangdongsheng keyan lingdao xiaozu zhu Hainan, 'Jieshao yige nongcun kexue shiyan xiaozu', 23 November 1969, Guangdong Provincial Archives, 306-A0.02-7-28, p. 7.

44 'Zhuangzu guniang xue Dazhai: Kexue zhongtian duo gaochan', Guangxi nongye kexue (1975) 7, pp. 32-35.

45 Shanxi sheng Xinxian diqu geweihui, Nonglin shuili ju keji xiaozu (eds.), Xinxian diqu nongye kexue shiyan, n.p., 1971, p. 36. 
1980s saw a dramatic ascendancy of technocracy, in which Deng Xiaoping ushered in the era of 'Four Modernizations' and a new class of what Joel Andreas has called 'red engineers' gained unprecedented economic and political influence. ${ }^{46}$ We saw above that in the case of India, by the 1980s critiques of the green revolution's technocratic blind spots had inspired new approaches to modernizing agriculture, though these efforts did little to foster true politically engaged epistemology and arguably continued to bolster technocratic power. The 1980s in China were not in any manner fertile ground for criticisms of technocracy. In China, critiques of green-revolution technologies based on environmentalism and the 'indigenous-knowledge' movement are a far more recent phenomenon than they are in India - so recent that perhaps it is too soon to determine their political significance. However, it is notable that even as they valorize farmers' knowledge and call for more collaborative frameworks within which scientists, agricultural extension workers and farmers can work together, they are usually careful to avoid association with the Mao-era scientific-experiment movement, which appears to have been thrown out along with the dirty bathwater of Cultural Revolution political strife. ${ }^{47}$

Still, the degree to which challenges to technocracy in agricultural development have focused on the 'traditional wisdom' of farmers suggests the need for a fuller exploration of the complex and conflicted attitudes modernizers have held towards farmers' knowledge. The next two sections will return to India and China of the 1960s-1970s to examine how these two states imagined the roles farmers would play, and the necessity of their transformation, in the process of remaking agriculture. Neither India nor China pursued the 'White Revolution' that made up William Gaud's second rejected pathway; these two states shared not only Gaud's repudiation of religious authority in politics but also a broader anxiety about the 'backwardness' of traditional forms of knowledge and social practice. But in neither case was the past easily overcome, and both states found themselves wrestling over how to create a new kind of farmer capable of implementing the new technologies they promoted.

\section{The green revolution and the making of 'modern' farmers in India}

Touring the foothills of the Punjab Himalayas in 1965, M.S. Randhawa, the director general of India's Intensive Agriculture Area Programme, was enchanted with the beauty of the new green-revolution cultivars. Unlike the 'pale strips' of traditional wheat, the new dwarf varieties growing in the terraced fields below the white mountains bore 'dark green' leaves. Fertilized with calcium ammonium nitrate and superphosphate, these crop varieties 'gave promise of a bumper crop'. Randhawa's observation brings to light how the discourse of green revolution in India had deliberately plaited together modernity and profit. ${ }^{48}$ But it was not just the landscape that was to be transformed:

46 Joel Andreas, The Rise of the Red Engineers: The Cultural Revolution and the Origins of China's New Class, Stanford, CA: Stanford University Press, 2009.

47 See, for example, Chen Tianyuan and Huang Kaijian, 'Canyushi zhiwu yuzhong yu kechixu liyong shengwu duoyangxing: yi Guangxi yumi wei li’, Zhongguo nongxue tongbao (2006) 22(7), pp. 490-494; Schmalzer, op. cit. (1), pp. 219-225.

48 M.S. Randhawa, 'The miracle of nitrogen', Indian Farming, June 1965. 
the green revolutionaries had their sights set on the cultivators as well. In place of 'traditional' cultivators, the green revolution depended on, and was expected to produce, 'modern' farmers.

Technocrats strove to bring about the changes they saw as necessary to achieve the larger economic goals of the Indian state. But instead of identifying structural obstacles to change, Indian supporters of the green revolution emphasized the personal characteristics that allegedly prevented farmers from adopting new technologies. Throughout the colonial and post-colonial periods, Indian farmers had been labelled 'backward', 'traditional' and even 'other-worldly'. Speaking in 1957 to the US agricultural attaché, for instance, P.N. Thapar, the secretary to the Indian government's Ministry of Food and Agriculture, complained that Indian farmers' prejudices and religious beliefs slowed productivity in the food crop sector. ${ }^{49}$ Arguably, farmers' deep-seated religious beliefs made handling of human waste a taboo and their 'other-worldliness' (as Weber famously put it) turned them away from the higher yields and increased profits that chemical fertilizers promised. ${ }^{50}$

The success of the green revolution appeared to depend on changing Indian farmers' attitudes toward technology, profit and modernity in general; at the same time, green revolutionaries suggested that adopting the technologies would serve as a catalyst to effect that change. To Norman Borlaug, the American agronomist known as the 'father' of the green revolution, the new technologies would not only 'trigger' a 'real revolution' in wheat production and so fight hunger, but also introduce 'dynamic new methods in one stroke ... [and] kill old ideas and methods' ${ }^{51}$ Prime Minister Indira Gandhi harboured a similar desire about the new technologies. Speaking to one of the largest congregations of scientists in the 1967 annual session of the Indian Science Congress, Prime Minister Gandhi observed the coming of an 'agricultural revolution' which she hoped would be successful not only in feeding India's 'growing numbers' but, more importantly, in leading to 'science, scientific temper, [and] a rational outlook' among farmers. ${ }^{52}$

For a significant number of Indian economists and agricultural scientists, success came to be measured both in the production of better crops and in the 'improvement' of the mental world of farmers so that they could partake in the green revolution's production miracle. Many of these improvement efforts took the form of convincing Indian farmers to be 'receptive' to the new agricultural inputs, particularly the dwarf seeds and chemical fertilizers. ${ }^{53}$ Thus the introduction of green-revolution technologies necessitated a new

49 Agriculture service report from senior agricultural attaché to the Department of Agriculture, Washington, 7 July 1956, 469.7, Records of the International Cooperation Administration (NARA), Box 1.

50 Max Weber, The Religion of India: The Sociology of Hinduism and Buddhism, New York: The Free Press, 1958, 326; Weber, The Protestant Ethic: The Spirit of Capitalism, Los Angeles: Roxbury, 2002, p. 1xiv.

51 Norman Borlaug to Mr J.A. Pelissier, 26 July 1965, Iowa State University, Special Collections, Norman Borlaug Papers, Box 5, Folder 20.

52 Indira Gandhi, Indira Gandhi on Science, Technology and Self-Reliance, Calcutta: Indian Science Congress Association, 1985, p. 10.

53 B. Sen, 'Opportunities in the green revolution', Economic and Political Weekly, March 1970, p. A-33; 'Mexican wheats and the Punjab farmers', Progressive Farming, September 1971 (Punjab Agricultural University), Norman Borlaug Collection, ISU, 15/12, pp. 15-18. 
level of emphasis on agricultural extension. Along with research and teaching, extension was made integral to all agricultural universities in India, which increasingly followed the model of the US land-grant colleges. The National Demonstration Programme, initiated by the Agricultural Ministry of the Indian government in 1965, took charge of much extension work and developed special programmes for women and children, along with visual aids to reach illiterate farmers. Experts with the programme clearly stated that 'the main objective is to demonstrate to the farmer the higher production potentialities of every unit area of his land'. ${ }^{54}$ These large-scale demonstrations were meant to 'showcase' the benefits of the new inputs. Responsibility for the programme was later transferred to the Council of Agricultural Research, indicating that agriculture was increasingly under the jurisdiction of scientists rather than, as in the past, politicians and civil servants.

Extension agents were charged with making farmers aware of the differences between the new and traditional varieties, educating farmers on ways to improve production, as well as developing in farmers an open, rational attitude towards modern technology. Often these goals overlapped as extension officials countered different kinds of 'prejudice' towards the new seeds - the red color of the kernels of some seeds, for example, triggered farmers' scepticism as it was unusual among Indian varieties. Moreover, though impressed with the production potential of the new varieties, Indian farmers often had concerns that ranged from how well the new seeds would survive in storage to their possible negative effects on human virility. ${ }^{55}$ However, extension was often successful. In the late 1960s, scientists at the Punjab Agricultural University, situated in the heartland of the green revolution, proudly reported that after they conducted agronomic trials on Kalyan 227 and Sonalika 308, 'the good news of the excellent performance of Mexican wheats spread like wild fire' and the farmers, thrilled to see these results, evidently 'tried to obtain the seed of these new varieties from any source at any price'. So eager were some of the farmers to access the new seeds that while visiting the research stations they even plucked handfuls of ripe ears and pocketed them, observed the station officials. ${ }^{56}$

The extension work among farmers involved, as Foucault would put it, several types of 'epistemic' measure to 'conduct the conduct' of 'men and things' ${ }^{57}$ Cultivators and the agrarian environment (particularly seeds, plant morphology, soil and groundwater resources) were both brought under the scrutiny of experts with the intention of better managing their development in the interests of the state. In facilitating the flow of research results to farmers, experts aimed at regulating the soil nutrients to the level optimum for the growth of dwarf seeds; farmers received instructions on ways to grow multiple crops in the same plot of land, devise means to control pest and disease attacks, and manage water resources in the region. Rather than leaving farmers to sort out agricultural problems on their own, relying on their experiences and received

54 'Mexican wheats', op. cit. (53), p. 18.

55 'Mexican wheats', op. cit. (53).

56 'Mexican wheats', op. cit. (53), p. 17.

57 Mitchell Dean, Governmentality: Power and Rule in Modern Society, London: Sage Publications, 1999, pp. 20-27. 
wisdom, extension experts organized field days where farmers got to discuss their problems with the farm scientists who advised them on ways to overcome production hurdles. ${ }^{58}$

To agricultural economists, subsistence farmers were not real producers as they consumed everything they raised: existing outside the money economy, they added little to the country's financial wealth. Hence the transformation of India's cultivators would not be complete unless farmers embraced a profit model of agriculture. One of the key strategies for effecting this change involved showcasing individual instances of success in an effort to convince a larger group of farmers to emulate their modern attitudes. Towards that end, farmers who achieved remarkable yields through the use of new technologies received coverage in the print media. In the saga of the war against hunger, 'modern' farmers proved the most convincing heroes.

One such farming hero was Kanwar Mohinderpal Singh. A farmer from the Delhi region, Singh became a familiar name to many. His claim to fame rested on the fact that he harvested nearly 8.4 tons of wheat per hectare, which was the highest yield so far recorded anywhere in the world in 1967 for a crop of 150 days' duration. Eager to project Singh's achievement as an instance worthy of emulation by other farmers, Dr M.S. Swaminathan, the director of IARI, and Dr S.P. Kohli, the coordinator of the All India Coordinated Trial, often referred to him in their writings. Mohinderpal Singh came to represent all those 'progressive farmers [who] adopt[ed] the high-yielding varieties for improving their financial conditions'. ${ }^{59}$ The vision of a hunger-free India came to revolve around these progressive farmers who, in discarding indigenous inputs, showed the rest of the country how to overcome backwardness and become modern.

In the rhetoric employed by experts, a farmer's 'progressivism' was related to his willingness to take risk. Risk taking was disassociated from its familiar connotations of 'gambling' or 'irresponsible' behaviour, and celebrated instead for its association with higher goals. ${ }^{60}$ Beyond the personal profit that the new technology promised, agricultural experts often evoked greater national needs, such as food security, rural prosperity and progressiveness. A worldwide 'fateful race' between population growth and economic development was widely cited by Indian technocrats, population experts, scientists and politicians coming from different places on the ideological spectrum. Though the proponents of the green-revolution technology were well aware of the very real possibilities of crop loss from pest and disease, as well as from inadequate watering, they urged Indian farmers to take the risk of growing the dwarf cultivars. Apparently, the development race could be won only if Indians showed willingness to take risks in all aspects of national life and salvage the time they had lost in the past. ${ }^{61}$

58 'Mexican wheats', op. cit. (53).

59 Das and Sarkar, op. cit. (28), pp. 63-64.

60 Sudhir Sen, A Richer Harvest: New Horizons for Developing Countries, New Delhi: Tata McGraw-Hill, 1974 , p. 49.

61 Sen, op. cit. (60), pp. 69-72. For a list of publications during this period on food and population discourse see Sterling Wortman and Ralph W. Cummings Jr, To Feed This World: The Challenge and the Strategy, Baltimore and London, Johns Hopkins University Press, 1978, pp. 85-87. 
The professed belief in taking 'calculated' risks was not unique to Indian technocrats but was consistent with the contemporary discourses of technocracy in circulation worldwide. ${ }^{62}$ Modernization theorists advocated risk taking as an essential quality in the social-psychological profile of a modern individual irrespective of national or cultural context. Arguably, people willing to take risks in adopting new technologies possess an attitude of 'openness to new experience', combined with a sense of 'trust' and a belief in 'efficacy', that permits them to see the world as following a lawful order in which humans 'exert considerable control over the environment'; such people were reportedly more inclined to give up traditional outlooks and habits. ${ }^{63}$ As tradition became a taboo concept among Indian technocrats, any action or position that tended to perpetuate it became the object of ridicule. For instance, the Secretary of Agriculture in India scorned local efforts to raise productivity using 'Lathi Sal', a traditional variety, instead of readily accepting Taichung Native-I, the newly introduced dwarf rice (1967-1972) developed in the International Rice Research Institute. ${ }^{64}$ Thus as risk taking came to be hailed in the technocratic circle as conducive to development, it also helped to impose a linear narrative of modernity in which a particular set of ideas, actions and inputs were championed over others.

Though apparently innocent stories of successful farmers, these heroic narratives reflected a confluence of multiple interests - those of the modernizing state, of ideologues of development and of agricultural capitalists, to name a few. The success stories are sagas of personal virtue, discretion and foresight; they lack any recognition of the social and cultural contexts that make a technology acceptable to some while excluding many others. As we will see below, in socialist China the social context - and especially with respect to class and gender - played a central role in narratives of model farmers. But that did not necessarily make such narratives more respectful of rural culture or more true to the experiences of all those who resisted the new technologies.

\section{Risk, revolution and resistance in China}

In India, traditional farmers' 'risk aversion' was seen as an impediment to the capitalist modernization of agriculture. The goal was to transform these farmers into 'risk-taking' actors whose farming decisions would promote investment and development. Chinese political and scientific leaders also faced the dilemma of how to engage with riskaverse farmers, but the different political context changed the stakes considerably.

When new technologies failed (and, of course, they frequently did), the unwillingness of 'old, poor peasants' to embrace risk was sometimes seen as demonstrating their valuable knowledge, rooted in long experience of labour (for Mao, the most reliable kind of knowledge there was), in contrast with the highly suspect fancies of would-be ivorytower scientists with little knowledge of farming realities and dangerous tendencies to

62 Sen, op. cit. (60), p. 72.

63 Alex Inkeles and David H. Smith, Becoming Modern: Individual Change in Six Developing Countries, Cambridge, MA: Harvard University Press, 1974, pp. 22-23.

64 Sivaraman, op. cit. 25 , p. 318. 
seek personal fame and glory through flashy new inventions. Such cautionary tales appear frequently in 1970s accounts of educated youth - especially urban youth participating in scientific experimental projects in the countryside. The solution in such accounts was often not just political consciousness-raising but specifically better respect for the wisdom of 'old peasants.' For example, in one such story, a group of urban, 'sent-down' youth in Hebei province failed to be guided by the experience of the 'old peasants'; instead, they sought to impress people by coming up with startling innovations, such as hybridizing cotton and paulownia to create a perennial 'cotton tree'. Their story served as a cautionary example about the importance of uniting with the masses. ${ }^{65}$ In a report published in 1966, leaders who sought to increase wheat production acknowledged that peasants were right to criticize them for their 'blind' approach that failed to begin with the needs of the masses to secure the support of the masses; the peasants had said they would 'have to sell their wives and children if they farmed like that'. ${ }^{66}$

On the other hand, when new technologies succeeded (or for political reasons needed to be acclaimed successes), risk aversion was often blamed on 'feudal' or 'reactionary' elements who sought to undermine science and the revolution. Before the escalation of state-sanctioned violence in 1966, even class-based opposition was often imagined as redeemable. A story written in late 1965 recounted the efforts of a youth, Zhang Yankao, to convince local people of the worth of his new seeds. Yankao planted his experimental field in patches of new and old seeds to demonstrate the different growth and yield patterns (recall the visible metaphoric representation of modernity and tradition in the Indian depiction of old and new wheat varieties above). However, some 'opinionated' members of the collective did not see it the same way: they objected to the field's uneven appearance ('like a spotted leopard') and concluded that Yankao had wasted a perfectly good piece of land. Yankao's scientific-experiment group reportedly received widespread support from poor and lower-middle-class peasants, but the vice team leader, an upper-middle-class peasant named Zhang Jiatao, allegedly opposed scientific experiment on the grounds that it was too 'cumbersome' and a waste of resources. However, when Yankao's methods achieved better results, Zhang Jiatao reportedly conceded - a happy ending all around. ${ }^{67}$ Later accounts exuded more vitriol. In one story, published in 1974 about an incident in spring of 1969, county leaders called on rural educated youth in a three-in-one experiment group to hybridize sorghum. The failure of the group's first experiments reportedly provided a chance for 'class enemies' (in this case, specifically 'rich peasants') to attack not only the experiment group but

65 Peter Seybolt (ed.), The Rustication of Urban Youth in China: A Social Experiment, New York: M.E. Sharpe, 1975 , pp. 60-63. This is a translation of a Chinese collection entitled Reqing guanbuai xiaxiang zhishi qingnian de chengzhang, Beijing: Renmin chubanshe, 1973. See also Heilongjiang sheng Binxian Xinlisi dui keyan xiaozu, 'Bai ying dadou wang de xuanyu', Nongye keji tongxun (1973) 12, p. 4; Zhang Renpeng, 'Houlu duizhang Yang Liguo kexue zhongtian chuang gaochan', Xin nongye (1974) 14, p. 26.

66 Henan sheng Nanyang zhuanqu kexue jishu xiehui (ed.), Quanguo nongye kexue shiyan yundong jingyan buiji, vol. 1, n.p., 1966, p. 5.

67 Kexue zhongtian de nianqing ren, Beijing: Zhongguo qingnian chuban she, 1966, pp. 29, 37-40. 
science itself. According to the account, success came to the youths after they had struggled against their enemies and made a deeper study of Mao's work. ${ }^{68}$

It was all well and good to criticize members of politically suspect classes for their 'reactionary' resistance to scientific farming. But no amount of political spin could prevent people from noticing that resistance to technologies favoured by the state frequently came from 'poor and lower middle peasants'. In such cases, peasants were not celebrated for their wisdom in adhering to traditional ways of farming that we might recognize as ecologically sustainable or supportive of social welfare. Rather, resistance was frequently blamed (just as in India) on the old bugaboos 'backwardness' and 'superstition'. In one account, the 'backward masses' were reportedly highly resistant to new vaccinations and a new system of breeding for swine, saying that the people trying to popularize these technologies were 'beggars from somewhere' trying to cheat them - a closer examination of the situation reveals that indeed the new technologies threatened the livelihoods of local veterinarians and boar-keepers. ${ }^{69}$ In another story, 'some backward commune members blamed a bad pea harvest on ghosts, after which no one wanted to plant the newly promoted variety. ${ }^{70}$ Superstition was also to blame in the case of a group of peasants who refused to plant in a 'dead people's field', a place where people had died after farming there. ${ }^{71}$ While such beliefs can well stand in the way of beneficial change, they also not uncommonly play important roles in local cultural ecologies - roles that the socialist Chinese scientific paradigm had no way of acknowledging.

The methods credited for quelling resistance and producing support for new agricultural technologies speak volumes to the state's perspective on science, risk and the construction of the modern farmer. Class struggle and political education played a central role in an explicit strategy to transform people's consciousness. But insisting that science accept 'politics in command' did not mean a failure to recognize the role of evidence-based argumentation. Rather, examples of resistance raised in official and popular reports typically at least included, and were often dominated by, accounts of successful efforts to convince peasants through empirical demonstration and rational argument. ${ }^{72}$ For example, when in the 1960s a seventy-nine-year-old 'old peasant' outside Beijing complained about the promotion of a new method of 'close planting' - saying, 'Planting so close is like beating people up, come autumn we won't have any grain to harvest' - the solution was to allow him to plant one field, and the experiment team would plant the other. After viewing the results, he reportedly acknowledged the validity of the new method. ${ }^{73}$ In the case of the pea-stealing ghosts, a variety of methods taken

68 Nongcun zhishi qingnian kexue shiyan jingyan xuanbian (Beijing: Renmin chubanshe, 1974), p. 36.

69 Henan sheng, op. cit. (66), p. 18.

70 Henan sheng, op. cit. (66), p. 4-5.

71 Hua xian Jiang Qizhang. 'Pinxia zhongnong yao dang kexue shiyan de chuangjiang', 1965, Guangdong Provincial Archives, 235-1-365-047 049, pp. 3-4.

72 The richest documents on resistance and efforts to convince peasants come from 1965 and 1966, when the scientific-experiment movement had just taken off and before the Cultural Revolution dramatically changed the political stakes.

73 'Yige shehui zhuyi jiaoyu yundong hou chengzhang qilai de keji xiaozu: Tongxian Xiji gongshe Zhaoqing dadui keji xiaozu', 15 November 1965, Beijing Municipal Archives, 2.22.31, pp. 42-49. This source details a number of similar examples. 
together proved effective to help people whose thought was 'blocked'. Cadres took the lead in doing experiments, the demonstration fields 'spoke' (that is to say, provided evidence), a man from another village with excellent pea crops was brought in as an adviser, and finally people were invited to sample the peas once they were harvested: 'as soon as they started chewing, their thought cleared up'. ${ }^{74}$

How does all this relate to what we have seen in India? Modernizers in both places wrestled to overcome resistance from farmers sceptical of new technologies. Whether cultivating 'risk-neutral' farmers capable of forwarding the capitalist modernization of agriculture, or revolutionary teams of peasants, cadres and technicians capable of building a 'new socialist countryside', the agents of green revolution faced the bogeys of 'tradition' and 'conservatism': in casting traditional forms of knowledge as 'superstition', they elided cultural context and so obscured the linkages between culture and knowledge - and in consequence they missed opportunities to tap the wealth of knowledge that farmers possessed about farming effectively and sustainably in their locales. Moreover, in both China and India proponents of agricultural transformation sought to convince through empirical evidence and demonstration that appealed to farmers' rationality; moreover they identified individuals who could be used as exemplars of the specific scientific values they wanted to instil in the population.

But in China the politics of socialist revolution changed the terms in which this struggle could be conceptualized. On the one hand, peasant resistance was always potentially a positive sign - after all, peasants were the backbone of the communist revolution and their deep experience of labour made them not just politically but epistemically more trustworthy than scientific elites. On the other hand, this perspective could only go so far, since the state was in fact deeply committed to modernizing agriculture. The spin was easiest when resistance could be pinned on 'class enemies'. However, in reality it was often poor and lower middle peasants themselves who presented opposition. The combination of political consciousness-raising and empirical demonstration that defined the response to such opposition in official reports suggests a confidence not only in the compatibility of revolution and science, but also in peasants themselves as politically reliable and fundamentally rational actors. Peasant resistance in account after account compelled cadres and technicians to increase the rigour of their experiments, or at least the persuasiveness of their demonstrations.

Despite the obvious frustrations that modernizers in Mao-era China experienced in attempting to transform agricultural technologies, and despite frequent disparaging references to the 'backward' or 'superstitious' tendencies of peasants, the ideological demands of the socialist revolution thus produced a very different official understanding of the meaning of peasant resistance than that found in India. To what extent that 'official understanding' reflected the actual feelings of cadres and technicians on the ground is another story. If post-Mao writings and oral history interviews are any indication, actual efforts to celebrate peasant wisdom may well have fallen considerably short of the ideal presented in Mao-era documents. The ideas articulated in stateproduced sources from the Mao era are nonetheless significant in that they represent a

74 Henan sheng, op. cit. (66), pp. 4-5. 
vision of peasants and the green revolution distinct from the dominant vision projected by the United States government and the green-revolution scientists it funded in places like India.

\section{Conclusion}

This paper has explored the unfolding of the green revolution in India and China, where 'red' (political revolution), 'white' (tradition), and 'green' (technocracy) were by no means as clearly demarcated as in William Gaud's 1968 rendering. India and China both adopted the new seeds and agro-chemicals of the green revolution. However, neither country fully adopted the larger US Cold War ideology or the specific greenrevolution epistemology - in particular, the technocratic insistence on separation of science and politics - that it supported. Even with official adoption of green-revolution technologies, state and non-state actors in India continued to express a range of views on what the green revolution meant for rural society, particularly its potential impacts on relations of production, agricultural landownership and local power structures. Thus the adoption of green-revolution technologies in India did not imply the absolute triumph of technocratic values; rather, experts constantly had to negotiate, seek validation and reinvent the role of technology in society. Chinese critics of the green revolution went considerably further: there, radical leaders insisted that technological change could never replace revolution in the social and political spheres, and they criticized what they saw as the Indian state's embrace of green revolution explicitly in those terms. Thus in China the new seeds, chemicals and associated technologies of the green revolution had to be pursued within a 'rural scientific-experiment movement' based on a radical epistemology combining peasant wisdom, party ideology and the modern technological knowledge of 'educated youth'. With respect to rural people, Indian and Chinese leaders alike embraced the values of modernization and committed to eradicating what they saw as 'backward' habits and 'superstitious' mindsets. However, in India the green revolution was intended to transform farmers into risk-taking, profit-making individuals, whereas the Chinese 'rural scientific-experiment movement' sought to produce a nationwide network of peasant agro-technicians supporting socialist agriculture.

After the death of Mao Zedong in 1976 and the birth of the reform era a few years later, China's new leaders embraced a dramatically new perspective on science and politics; today, the Chinese state is, if anything, more wedded to a technocratic vision of agrarian modernization than is the Indian state. The apparent triumph of green revolution over red in both countries raises the question of how much, at the end of the day, the ideological differences between 1960s-1970s China and India mattered to historical outcomes. A partial answer to that question may be found in Diganta Das and Tong Lam's article on science parks in this issue: they show how much power the new neoliberal political economy in both China and India has in redefining what is inside the borders of science (namely business interests) and what is outside (namely democracy).

However, as Pin-Hsien Wu's contribution to the issue demonstrates, the degree of state involvement in discourse production makes a big difference to the impact of environmental organizing. Wu shows that the PRC state has played a very strong role in 
defining the parameters of Chinese environmentalism. Similarly, as this article shows, in China the Mao-era state took the leading role in articulating the critique of technocracy in agricultural science, and today's movements for environmental and social justice in agriculture echo that Mao-era rhetoric even as they participate in more global currents supporting indigenous knowledge, seed sovereignty and other related causes. In India, on the other hand, environmentalist discourse and critiques of technocracy have largely been generated by non-state actors. Although we have seen the potential in India for the state to coopt oppositional discourse and reinforce technocratic power, the stronger precedent for non-state organizations in producing such discourse in the first place may well provide greater scope for challenging the fundamental assumptions of agricultural technocracy as it gains new power in the neoliberal order. 